\title{
Reconsidering Hamartia as "Sin" in 1 Corinthians
}

\author{
Erin Roberts \\ Department of Religious Studies \\ University of South Carolina, Columbia, SC 29208, USA \\ erinroberts@sc.edu
}

\begin{abstract}
English translations of the New Testament (NT) consistently render the Greek term hamartia and its cognates as "sin." English translations of other Greek texts dated to roughly the same time period, however, provide a variety of English words such as "mistake," error," or "things we get wrong," to accommodate contextual nuances. This essay argues that this bifurcation has several unappealing consequences for the study of Christian beginnings. The palpable difference in translation portrays the NT texts as unique departures from the moral discourse of the time and reifies an unnecessary divide between early Christian and other kinds of moral literature, while the unqualified use of the English word sin brings with it the possibility that readers will import more unified theological doctrines about sin onto texts written well before the doctrines were even developed.
\end{abstract}

\section{Keywords}

sin - hamartia - New Testament - Paul - 1 Corinthians - translation

Despite efforts to redescribe the beginnings of Christianity in a way that adheres to more rigorous theoretical and methodological standards of historical inquiry, there still remains a problem in the way the text of the NT is

Versions of this essay have been read at the 2010 NAASR panel, "Translation, Anachronism, and Ideology in Scholarship on Early Christianity," the 2011 Constructing Christianity Conference at the University of South Carolina, and at the January 2012 meeting of the Center for the Ancient Mediterranean at Columbia University. William V. Harris and Heike Sefrin-Weis read and commented on drafts at various stages. 
currently packaged for English-speaking consumers: the translation of certain words reflects theological concepts that would not necessarily have been within the range of possible meanings for ancient authors and audiences. ${ }^{1}$ The choice of certain English terms implies the existence in antiquity of a set of social, religious, and theological interests that, while readily comprehensible and applicable to modern sensibilities, does not necessarily align with historically plausible interpretations. Students and scholars interested in the ways that ancient authors and audiences could have understood certain concepts could benefit from an awareness of the extent to which modern concepts have become embedded in current English translations. ${ }^{2}$

In 1989 , the NRSV was released to replace the $1946 \mathrm{RSV}$, and currently is used widely in university, seminary, and divinity school classrooms because it is thought to be one of the better-if not the best—academic translations available. Nevertheless, the NRSV's translation of certain Greek words serves to reinforce particular modern ideologies. One example is the deliberate and consistent use of gender-inclusive language in the NRSV, which yields puzzling and inconsistent results (Kraemer et al. forthcoming). In the NRSV, unlike the RSV, the Greek term adelphoi (brothers) has a fairly broad semantic range, including "brothers and sisters," "people," "friends," "fellow Israelites," "family," "believers," "relatives," and "comrades." This gender inclusivity shows up disproportionately in the NT, giving the impression that the early Christians represented therein were attuned to modern sensibilities about gender inclusivity. By contrast, English translations of nearly all other literature of the time, be it within Greek, Judean, or non-canonical early Christian texts, do not employ consistent gender-inclusive language, with the implication being that only those Christians thought to be represented in the pages of the canonical NT were practicing gender inclusion/equality.

In addition to the case of adelphoi, there are other problematic translations such as the transformation of pneuma from a physical substance into a distinct personal being, the polemical translation of ta ethne as "pagan," and the reification of the rather nebulous social formation, called ekklēsia in Greek,

1 Of course, there are many ways to approach biblical interpretation and not everyone will see this as a problem. Those with commitments to at least some of the principles of historical criticism, though, will likely understand and acknowledge the pitfalls of anachronistic translation.

2 The students and scholars I have in mind need not only be imagined as those at secular institutions, for as Dale Martin has clearly shown, the methods and assumptions of historical criticism exist within seminaries and divinity schools across the theological spectrum (Martin, 2008). 
into a full-scale institution called, anachronistically, a "church" (Eyl, this volume). There is also hamartia, a term that has enjoyed a fairly flexible semantic range throughout its history, except for its appearances in the NT. If the variety of English terms used to translate adelphoi marks the canonical texts of early Christianity out as unique among other literature regarding an ideology of gender inclusivity, the singular translation of hamartia marks it out as unique regarding its persistent interest in $\sin .^{3}$

There exist many Greek texts from the first century that do not deal with the early Jesus movement or Christ-followers but nevertheless also utilize the word hamartia and its cognates. Except in the cases of texts specifically addressing Judean traditions (such as Philo of Alexandria and Josephus), though, one would be hard-pressed to detect-in English translations- that authors such as Musonius Rufus, Epictetus, or Plutarch, shared with the authors of NT texts an interest in sin. In the same way that gender inclusive translations of adelphoi depict early Christians as unique in their sensitivity to a more modern issue, translations of hamartia depict them as unique in their interest in the problem of sin and, consequently, its allegedly inevitable solution through Jesus Christ. I suggest that the palpable differences between translations of ancient philosophical texts, on the one hand, and ancient religious texts, on the other, likely stem from modern ideas about the essentially religious or theological nature of the English word sin; underlying this problem, though, is the added complication of the categorization of ancient texts as either "religious" or "philosophical," which belies the more modern idea that religion, theology, and philosophy were discrete fields in antiquity. The essay begins with a brief description of the ways that the English word sin is depicted in contemporary discourse in order to show that sin is commonly understood to be a religious concept; further, it points out that the categorization of sin solely as a religious term is at odds with ancient Greek usage, where the term is found in both religious and non-religious contexts. The next section focuses on the evolution of hamartia to show its semantic flexibility and introduces a debate concerning Aristotle's use of hamartia as an analogue for the kind of semantic expansion that I suggest. Finally, the essay concludes with some general comments about the Pauline corpus and a discussion about 1 Corinthians as test case for my proposal that hamartia need not invariably be translated as "sin."

3 The only exceptions are Acts 25:8, where the NRSV translates hēmarton as "committed an offense" and the RSV as "offended," and 1 Peter 2:20, where the NRSV translates hamartanontes as "doing wrong" and the RSv as "do wrong." 
In contemporary English usage, the term sin functions as a specifically religious term. This holds true for popular use as well as for more technical academic contexts. A survey of popular dictionaries, encyclo-, and wiki- pedias shows sin to be the term that designates a willful offense against God, God's will, or at least against the human moral codes modeled after God's will. ${ }^{4}$ Examples include $\sin$ as a "transgression of divine law; the sin of Adam"; "an offense against religious or moral law," "transgression of the law of God," "a vitiated state of human nature in which the self is estranged to God."6 Along similar lines, the Oxford English Dictionary defines sin as "an act which is regarded as a transgression of the divine law and an offense against God; a violation (esp. willful or deliberate) of some religious or moral principle."7 Solidifying the connection between sin and religion in popular discourse, is the featured illustration on the Wikipedia entry for sin: a fresco detail from the Sistine Chapel, which "depicts the expulsion of Adam and Eve from the Garden of Eden for their sin of eating from the fruit of the Tree of the knowledge of good and evil." Additionally, one may learn on this page that "atheism often draws a distinction between sin and an ethical code of conduct" and, "as the term is generally associated with theological belief, atheists do not typically use the word."

Similarly, resources for religion and theology claim "sin" as a technical term of their own and associate it explicitly with the kind of wrongdoing that is disruptive to human relations with the divine. Drawing upon ideas about the universal anxiety of humankind expressed by authors such as Mircea Eliade, Paul Ricoeur, Martin Heidegger, and E. R. Dodd, the entry on sin and guilt in The Encyclopedia of Religion states that, "In short, from being anxious, man became unhappy, stricken with guilt feelings about an initial accident that is repeated endlessly throughout human existence and can be called 'sin' ... [sin and guilt] come in a great variety of shades, according to the various

4 While a brief survey of online reference tools is not a comprehensive report on popular usage of the word, it does offer some degree of insight into popular understanding.

5 "sin," Online: http://dictionary.reference.com/browse/sin [accessed on January 21, 2013]. The second definition emphasizes willful intent and broadens the scope to include "some religious or moral principle."

6 "sin," Online: http://www.merriam-webster.com/dictionary/sin [accessed on January 21, 2013].

7 "sin," Online: http://www.oed.com/view/Entry/180030?result=1\&rskey=2yftIf\& [accessed on January 21, 2013].

8 "sin," Online: http://en.wikipedia.org/wiki/Sin [accessed on January 21, 2013].

9 "sin," Online: http://en.wikipedia.org/wiki/Sin [accessed on January 21, 2013]. 
sensitivities represented by the great number of religious and philosophical feelings and systems" (LaCocque 1995: 325). After a brief introduction to humanity's primitive interest in magic, myth, and the more general category of the numinous, the entry is divided into sections covering Mesopotamian religion, the religions of Israel, the Greeks, the Christian Church, and Islam. Thus the overall impression is that sin is a specifically religious problem, mainly found within the trajectory defined by an insider account of the history of Christianity. In other words, the entry essentially traces a version of the concept of sin through the usual Christian stages, beginning with Mesopotamian and Israelite myth and religion, ${ }^{10}$ touching upon "the Greeks," and then offering a description of sin in the Christian church (Irenaeus, Origen, and Augustine). Finally, the entry concludes with a brief paragraph on Islam. Taken together, the Encyclopedia's discussion of sin defines it as a universal human problem that is expressed primarily within the domain of religion (and more specifically, within those of the Abrahamic tradition).

The Routledge Encyclopedia of Philosophy also connects sin to Abrahamic religious traditions: "The concept of sin is the concept of a human fault that offends a good God and brings with it human guilt. Its natural home is in the major theistic religions of Judaism, Christianity and Islam" (Quinn 1998: 791)."1 The entry then moves into a discussion of "actual sin" as individual human acts of wrongdoing. Some acts, like murder, are morally wrong in themselves and yet are "doubly wrong [i.e., sinful] when forbidden by God" (Quinn 1998: 792). Other actions, such as not showing gratitude to God, are neither morally wrong nor sinful apart from the existence of a beneficent God. A third kind of "actual sin" stands apart from morality altogether and are labeled wrong only in a particular religious context wherein God has decreed a particular kind of practice (worshipping on one day as opposed to another, for example). The entry goes on to distinguish between "objective and subjective actual sin," but my point in mentioning the three-fold categorization of actual sin is to highlight the fact

And yet the section on the religions of Israel concludes thusly, "In summary, the final answer to our guilt, according to the New Testament, is given by the death of Christ which overcomes our state of sin and guilt and thereby inaugurates the kingdom of God on earth" (LaCoque 1995: 328-329).

The entry details the differences between the three Abrahamic traditions as follows: "In the Hebrew Bile, sin is understood within the context of the covenantal relation between Yahweh and his chosen people. To be in covenant with Yahweh is to exist in holiness, and so sin is a deviation from the norms of holiness. In the Christian New Testament, Jesus teaches that human wrongdoing offends the one whom he calls Father. The Qur'an portrays sin as opposition to Allah rooted in human pride" (Quinn 1998: 792). As we will see, however, this is an over-simplification that under-emphasizes non-religious aspects. 
that the author has subtly, yet consistently, differentiated between actions that are morally wrong and those that are sinful; moral wrongs need not (but can) involve a religious context, whereas sins necessitate one. ${ }^{12}$

That contemporary resources isolate religious from non-religious conceptions of wrongdoing by associating sin with willful offenses against God is not, in itself, problematic. It is simply the way the term has evolved in contemporary usage, possibly reflecting ideas about religion as a discrete, identifiable, realm or sphere of activity. The problem at issue in this essay is not contemporary popular usage of the term, but rather is that translators have not critically examined whether the source language is properly represented by the choices in the target language. ${ }^{13}$ Uncritical acceptance of the sameness of contemporary Christian conceptions of sin and the semantic range of hamartia, though, is merely one aspect of a type of biblical criticism that Stanley K. Stowers has recently termed "academic Christian theological modernism," one of the defining characteristics of which is that the "religion, morals, sociality, and subjectivity, [of] the early Christians are the same as us. They are the same people in different clothes, with a different 'science.' The early Christians are not only generally the same as modern Europeans, but also the same as the professors and Christian scholars who study them in their focus on spiritualized intellectual interests, that is, doctrines, theology, and ideas" (Stowers 2011: 106-107). In the case of translation practice, the assumed sameness can refer to many of these variables; in the case of hamartia in New Testament texts (and especially in Paul) the problematic assumption is that it is a technical term that designates a robust and unified theological doctrine of human sin, whose only viable solution is salvation through Jesus Christ. Before turning to

The Routledge Encyclopedia is not alone in its identification of $\sin$ as a religious/ theological concept. See, for example, the definition of sin in the Oxford Dictionary of Philosophy: "A moral category going beyond that of simple wrongdoing by its implications of evil, disobedience, depravity, stain, and wickedness. Sin therefore requires atonement, penitence, and self-abasement, not to mention punishment. The abjection and lack of self-respect implied in the cluster of ideas serve to emphasize the importance of redemption. They are therefore an important buttress to the power of those who claim to know how to provide it. The concept is only at home in a religious tradition built around the possibility of God's disgust, and is not found pure and simple in classical thought, where offences were equally liable to divine vengeance whether voluntary or not" (Blackburn 2005: 340).

13 Although my focus in this essay is on translators of "religious" texts, who overdo their use of the word "sin," translators of "philosophical" texts, who mostly resist using the word, are also complicit in reifying the boundaries between what we now take to be essentially "religious" and "philosophical" texts. 
the New Testament, though, a discussion of the history and flexibility of the term hamartia is in order.

We have seen that the English term sin functions in a fairly specific way to designate either a kind of human error that arouses varying levels of disapproval from a deity, or an inborn feeling of guilt or emotional pain that is expressed within religious or theological contexts. As such, the use of the word sin is not necessarily the best choice for wrong actions that do not involve direct deviation from divine decree, do not arouse the ire or displeasure of a deity, or are otherwise not associated with theological/soteriological consequences. ${ }^{14}$ With reference to the use of hamartia in our source language, however, we will see in the next section that the situation is not nearly as precise.

The Greek noun hamartia and its cognates have been in use since Homer, and tracing the evolution of the use of the term up through Aristotle shows three main categories of meaning, none of which specifies an exclusively religious one that corresponds to modern popular and scholarly usage. First is the original, literal sense, commonly translated into English as "miss," meaning physically to miss something, to fall short, or go astray of a goal or target. Homer used the word frequently in battle scenes, to conjure images of hitting or missing intended targets (Bremer 1969: 30-31). This meaning is most prominent

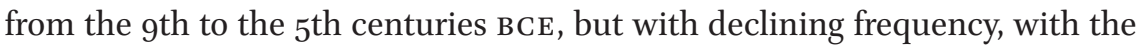
result that neither the Septuagint nor the NT use the word in its literal sense.

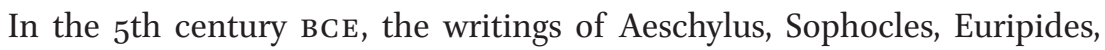
Herodotus and Thucydides show a decided movement toward two other senses of hamartia, usually translated as "err" and "offend." "Error" relates to actions stemming from good intentions but which nevertheless fail to meet their intended goals; "errors" are basically mistakes that do not result from any ill will or intentional deviation from a moral standard. "Offenses," however, amount to moral deviation because of the willful nature of actions such as intentional law-breaking, harm, or other such series offenses. Even here, though, the sense of hamartia need not be linked exclusively with divine moral standards or punishment. This does not mean that divinities were not thought to be associated with human immorality, for there was a popular belief that offenses (hamartemata or hamartiai) were recorded by Zeus. Similarly, in the $5^{\text {th }}$ century hamartia could refer to actions that provoke the gods to take

14 Cases of civic law-breaking, for example, are commonly called crimes rather than sins. 
revenge, but this frequency does not allow us to conclude that every use of the term requires this interpretation (Bremer 1969: 31-47).

It was in the 4th century BCE, especially in the writings of Aristotle, that occurrences of hamartia and its cognates were seen to relate to morality and agency in a more sophisticated way. ${ }^{15}$ Aristotle's discussions of the relationship between hamartia and other terms such as adikia (wrongdoing, injustice) and atuchia (misfortune, mishap) in the Nichomachean Ethics are of particular importance, as is his treatment of the role of hamartia in tragedy in the Poetics. We turn first to the topic of the difference between hamartia, adikia, and atuchia. Aristotle explains:

There being three kinds of harm, then, in interactions, the cases where ignorance is a factor are mistakes [hamartèmata], i.e., when the person affected, or the action itself, or the instrument, or the effect is not what the agent supposed, because he did not think he was hitting the other person, or not with this, or not this person, or not with this effect, but turned out not to be the effect he thought (e.g., he had it in mind not to wound, but only to nudge)... Now when the harm occurs contrary to reasonable expectation, it is a misfortune [atuchèma]; when it could reasonably have been expected, but is inflicted without bad intent, it is a mistake [hamartèma] (since it is a mistake when the origin of what causes the effect lies in the agent, but a misfortune when it is outside him); when a person inflicts harm knowingly but without prior deliberation, it is an unjust act [adikēma], e.g., things done through temper and other affections that are inevitable or natural for human beings, since those who inflict harm or go wrong [hamartanontes] in this way are doing what is unjust, and theirs are unjust acts, yet this does not mean that they themselves are unjust, or bad characters, because the harm did not come about because of badness; and when the harm is inflicted as a result of decision, then the doer is unjust [adikos] and a bad character (Nicomachean Ethics 1135b11-26, Rowe).

In this passage, Aristotle has categorized three kinds of harm, introduced the idea of agency, and considered the nature of intent.

15 Although Plato does use the term in moral and ethical ways, neither he nor other writers from the 4th century offer an explicit differentiation of the ways hamartia may be used or how it could be distinguished from related terminology, such as adikia (Bremer 1969: $47-52)$. 
One kind of harm is the misfortune or accident (atuchèma); a misfortune is something that befalls a person, is unexpected, and is not related to intent or agency. Another sort of harm is an unjust act (adikēma), and unlike misfortunes, unjust acts are related to agency. The first kind of agency would be when a person loses control of her emotions or is otherwise out of control (in an akratic state) and purposefully harms someone or causes damage. She is responsible for her actions and initiated them with the intent to harm, but later, after returning to her normal condition, realizes that she did something wrong and may regret it. The second kind of agency initiating an unjust act also involves an intent to do damage or harm, but unlike the first case, the agent is not under the sway of fluctuating passions; instead, this kind of harm is done because bad character (kakia) and malicious intent motivated the action. In both cases the resulting action is unjust, damaging, and wrong; the agent hit her intended target and thus did not commit hamartia. The second case, though, is worse because the person cannot realize, after the fact, that the outcome was wrong; save for a major moral turnaround, this is simply a bad person. With the first case, although the agent hits her intended target (causes harm) while she is out of control, upon coming to her senses nevertheless feels that something went awry; perhaps this is why Aristotle says that those who go wrong in this manner (hamartanontes), even though they committed an unjust act, nevertheless made a mistake.

The idea that harm can come about through some kind of mistake brings us closer to the meaning of hamartia. Unlike a misfortune (atuchèma) and unlike the unjust act (adikèma), the mistake involves no ill intent. We saw that the unjust act may come about in two ways, but the variables that trigger mistakes are innumerable. One example of a mistake would be intending to nudge a person but ending up wounding them (maybe the person you nudged was standing on an unstable surface and they ended up falling down and getting hurt); the intended aim was to get the person's attention but the result was that the person became injured. The nature of the intent was by no means malicious, but unlike the non-malicious doer of an unjust act, the person who makes a mistake is not necessarily under the duress of temper, passion, or akrasia more generally. Instead, these actions could be described as cases where an agent chooses a well- or neutrally- intended ${ }^{16}$ course of action that fails or "misses

16 By neutrally-intended I simply mean not having a bad intention. Not all mistakes stem from someone's trying to do something morally good, but could relate to actions we would say have little to no moral value, such as hitting the clutch instead of the break when driving a car with which one is unfamiliar. 
the mark," so to speak. Hamartēmata, then, are not necessarily willfully malicious deeds stemming from ill-intent. We have already established that when harm occurs due to an external impetus out of the control of the agent, it is not a mistake but rather a misfortune (atuchèma), and that harm resulting from illwill or an akratic state is an injustice (adikia). How does it happen, though, that a well-intended action could do harm without the agent's being a bad person?

As mentioned above, a particular course of action can lead to a mistaken result in several different ways. In his consideration of tragedy, Aristotle considers the number of ways that mistakes can happen; a good tragedy depends not upon a bad person ending up in ruins, but rather a well-intentioned person (otherwise the audience would have no sympathy or pity for him). Here, I introduce two ways that from well- or neutrally- intentioned decisions can go wrong: (a) ignorance of a fact or (b) lapse in judgment (Sherman 1992: 185-186). Oedipus, for example, intentionally killed a stranger who turned out to be his father. This was the result of a case of mistaken identity, which amounts to ignorance of a fact. Phaedra, however, who voiced her love for her stepson Hippolytus to someone who betrayed her trust, illustrates a classic case of poor judgment and not ignorance of a fact. Although neither Oedipus nor Phaedra would be considered morally bereft or culpable, both were responsible in a causal way for the tragic outcomes, and the nature of the causal relationship (and thus the nature of the mistake) was different for each. One was a mistaken belief stemming from ignorance of a fact, and the other was an error in judgment. Both kinds of harmful results, however, are covered by the term hamartēma. ${ }^{17}$

In a way similar to arguments in the field of Pauline studies over whether sin is an enslaving power, an inherited ontological flaw, or something else, scholars of Aristotle have discoursed about whether hamartia is best viewed as a tragic flaw, ignorance, or bad judgment (Bremer 1969: 52-56; Halliwell 1998: 202-237; Kim 2010; Sherman 1992). The "tragic flaw" interpretation focuses on the motif of retribution, and says that the life of the protagonist ends in ruins as a punishment for his errors and offenses. This interpretation is appealing to some degree, but some have pointed out that this reading does not fit a case like the Oedipal tragedy, where the wrongdoing did not come about as punishment for wrongdoing, but rather because of a series of unintended mistakes (Sherman 1992: 179). To conclude, though, that the nature of hamartia should be summed up as a "mistake of fact," has problems of its own. Mistakes from circumstantial

17 Further discussion of intent, agency, and the complications of voluntary and countervoluntary actions may be found in Aristotle, Nicomachean Ethics 3.1. 
ignorance may work for interpreting the nature of the Oedipal hamartia, but Aristotle is less interested in tracing the nature of unintended mistakes than he is in exploring the relationship between a person's character and the ensuing hamartemata or hamartiai. He wants to figure out how the many variables involved in a person's desires, thoughts, and beliefs may have come together in a way that leads to a tragic end (Sherman 1992: 179-180).

The multiplicity of ways that one may go astray seems to drive Aristotle's analysis of the ideal tragedy in Poetics 13-14. Aristotle maintains that the finest tragedies have complex plots and Stephen Halliwell argues convincingly that it is the indeterminacy of a precise definition and function of hamartia that enhances the complications of tragedy; he cautions that, "the first point which ought to be urged in the interpretation of hamartia, contrary to much traditional practice, is that it is not to be extracted from its context and treated as a concept or theory complete in itself" (Halliwell 1998: 215). Based upon several different reasons, including the fact that hamartia is "an appositely flexible term of Greek moral vocabulary" (and perhaps even more complicated by Poetics 13), Halliwell argues that hamartia ought not be viewed as a technical designation for a specific Aristotelian doctrine. He also addresses questions of translation, making a point similar to the one I argue with reference to the NT: "no particular English translation evidently recommends itself for this term [hamartia]. It is especially difficult to commit oneself to a single equivalent in view of the fact that several of the possible candidates-error, fault, mistake, flaw - have been closely associated with various attempts to pin the word down to a restricted sense," and, further, that "there is much to be said, somewhat ironically, for avoiding a consistent translation for the term" (Halliwell 1998: 222).

Before applying Halliwell's argument directly to NT texts, though, I mention a few factors that caution against using the Aristotelian case as a direct analogue. First, in the Poetics, Aristotle focuses on hamartia as one of several factors to explain the appeal of different sorts of tragedy, and, second, Halliwell's argument for semantic differentiation relies, in part, upon the complicated and unstable nature of tragic reversals. While one may regard the NT's presentation of hamartia as tragic, the texts themselves are not in any formal sense tragedies, nor do any of the texts purport to analyze the components of the genre of tragedy. In addition, Aristotle lived and wrote in the 4th century $\mathrm{BCE}$, and his use of the term does not necessarily translate into a plausible semantic range for the 1st century CE. A preliminary survey of some texts Greek texts from the ist century, though, shows that there does in fact exist a flexible range of meanings attributable to hamartia and its cognates and that 
the term need not be implicated explicitly with a kind of willful wrongdoing against God. ${ }^{18}$

Through an examination of the writings of Epictetus, for example, one finds that hamartia and its cognates are used in a number of ways. Errors in argumentation and logic (Diatribai 1.7.30-33), failure to pay attention (Diatr. 4.12), not doing what is appropriate (Diatr. 1.26.5-7), living in the grip of the passions (Diatr. 2.1.21-28; 4.1.1-5), and not living according to divine law (Diatr. 3.24.4043) all fall under the purview of hamartia, and translators have reflected this variety with a range of English terms.

In addition to using hamartia to represent a range of human mistakes or errors, Epictetus associates them with ignorance. In one passage, for example, Epictetus offers advice about how a child might address a father who is angry about his study of philosophy:

Very well then, father, I go astray [hamartanō], not knowing what is incumbent upon me or what my duty is. Now if this is a thing that can neither be taught nor learned, why do you reproach me? But if it can be taught, teach me; and if cannot do this, allow me to learn from those who profess to know. Really, what is your idea? That I intentionally fall into evil and miss the good? Far from it! What, then, is the cause of my going astray [tou hamartanein me]? Ignorance. Very well, do you not want me to put away my ignorance? Whom did anger ever teach the art of steering, or music? Do you think, then, that your anger will make me learn the art of living? (Diatr. 1.26.5-7, Oldfather)

The suggested appeal for education revolves around the claim that going astray is the direct result of knowing neither the proper goals of life nor how to pursue them. He emphasizes the fact that mistakes involve agency, but that the agency is a malleable one that can be remedied with instruction and correction.

Elsewhere, Epictetus considers why it is the case that people tend to be more willing to admit a mistake (hamartēma) than an unjust act (adikêma). He surmises that "in the case of most errors [hamartēmatōn], the principle reason why men are inclined to admit them is that they conceive that there is an involuntary element in them, as, for instance, in timidity and pity," but that "injustice [adikon] they do not at all conceive of as involuntary" (Diatr. 2.21.6-7). retains a variety of nuances. Incidentally, neither Epictetus nor Musonius Rufus uses the literal meaning of hamartia. 
Although Epictetus attributes such reasoning to confused people, ${ }^{19}$ the passage identifies hamartia as a mistake or error and distinguishes it from a willfully malicious wrongdoing.

Epictetus also uses hamartia to refer to more serious offenses such as repeated wrongdoings that might only be stopped through an appeal to the divine. He describes the state of a person who has made so many mistakes he can hardly recognize right from wrong: "But if you be once defeated and say that by and by you will overcome, and the second time do the same thing, know that at last you will be in so wretched a state and so weak [hexeis kakōs kai asthenōs] that by and by you will not so much as notice that you are doing wrong [hamartaneis], but you will even begin to offer arguments in justification of your conduct" (Diatr. 2.18.31-32). He also offers advice on how one might break out of this kind of state: "Remember God; call upon Him to help you and stand by your side, just as voyagers, in a storm, call upon the Dioscuri. For what storm is greater than that stirred up by powerful impressions which unseat the reason?" (Diatr. 2.18.29). In addition to associating one's release from repeated hamartēmata with the divine, Epictetus also uses hamartia to indicate the kinds of mistakes that come from living against divine law. In a passage rebuking those who claim to be Stoics but nevertheless pursue pleasure as a good, Epictetus compares such behavior to a false claim upon Roman citizenship:

Well, but those who falsely claim Roman citizenship are severely punished, and ought those who falsely claim so great and so dignified a calling and title [Stoic] to get off scot-free? Or is that impossible? Whereas the divine and mighty and inescapable law [ho nomos theios kai ischuros kai anapodrastos] is the law which exacts the greatest penalties from those who are guilty of the greatest offenses [tōn ta megista hamartanontön] (Diatr. 3.24.41-43). ${ }^{20}$

Of note is that even in cases where hamartia denotes either a state of wrongdoing that requires attention to the divine or an offense against God, as in Diatr. 2.18.29-32 above, English translations do not use the word $\sin ^{21}$

19 He goes on to say that people are, in some sense, responsible for all sorts of mistakes.

20 The penalty for one who disobeys divine governance is to "be abject, be a slave, suffer grief, envy, pity,- -in a word, be miserable and lament" (3.24.43).

21

This holds true not only for the Oldfather translation, but also for others as well. Matheson (1916) renders the hamartaneis of 2.18.31 as "you are going wrong," and Carter (1807) and Higginson (1890) as "you do amiss." Terms used with frequency in all of the mentioned 
Epictetus's teacher, Musonius Rufus, also uses hamartia and its cognates to cover a wide range of situations, with the bulk of the occurrences referring not only to mistakes and errors, but also to offenses and more serious wrongdoings. Civic law-breaking (Musonius 2.5), moral errors (2.12), mistakes in medical care, music, steering (2.13-14), mocking, insulting, or hitting someone (10.14-26), adultery (12.20-30), eating without moderation (18B.20-38) and even impiety toward the ancestral gods and Zeus (15A.1-21) fall under the purview of hamartia. Nevertheless, even with a good deal of the references referring to the kinds of wrongs that we might be inclined to say are more serious than a mistake, the most recent English translation of Musonius Rufus never once uses the word sin, even when the text associates hamartia with an offense of Zeus or the ancestral gods (King 2011). Musonius 15, which argues for following civic laws that prohibit the prevention of conception and intentional miscarriages, connects deviations of these laws with impiety:

By doing this, wouldn't we be wronging [examartanoimen] both our ancestral gods and Zeus, who guards the family? The person who is unjust [adikos] towards strangers wrongs [hamartanei] Zeus, the guardian of strangers, and the person who is unjust [adikos] towards his friends wrongs Zeus, the god of friendship. Likewise, the person who is unjust [adikos] towards his own family wrongs [hamartanei] his ancestral gods and Zeus, the protector of families who takes note of crimes [hamartēmatōn] connected with families. Anyone who wrongs [hamartanōn] the gods is impious [asebēs] (King 2011: 62).

By connecting an act of injustice toward another human with wronging the god charged with watching over a particular aspect of human sociality, Musonius turns what might today be seen as a civic or secular misdeed into a religious or theological one. ${ }^{22}$ If any use of hamartia would warrant the English translation "sin" (based upon considerations of today's common use of the term), this passage would surely be in the running.

Interestingly, King's 2011 translation deviates from the only other English translation in this very manner, for Lutz did use "sin" to translate offenses against the gods:

English translations of Epictetus include "error," "mistake," "offense," "fault," "misbehavior," "going astray," "doing wrong," and "going wrong."

22 This is not unlike Matthew 25:34-45, which associates the mistreatment of others with the mistreatment of the Son of Man, or 1 Cor. 8:12, which equates harming one's brothers with harming Christ himself. 
How can we help committing a sin [examartanoimen] against the gods of our fathers and against Zeus, guardian of the race, if we do this? For just as the man who is unjust to strangers sins against [hamartanei] Zeus, god of hospitality, and one who is unjust to friends sins against Zeus, god of friendship, so whoever is unjust to his own family sins against [hamartanei] the gods of his fathers and against Zeus, guardian of the family, from whom wrongs [hamartēmatōn] done to the family are not hidden, and surely one who sins against [hamartanōn] the gods is impious (Lutz 1947: 97, 99).

It was only in these four instances, though, that Lutz used the word sin, and I can only speculate that she did so because of the notion of harming or offending the gods. ${ }^{23}$

Thus far, the survey of the evolution of hamartia from Homer through Epictetus has shown it to be a flexible term that can cover a variety of human actions: missing an intended target in the literal sense, making a mistake in logic or argumentation, harming or wronging another person or oneself due to a lack of knowledge or poor judgment, behaving in a manner not fitted to a particular moral standard, being under the influence of one's passions, acting in an unjust manner while under the sway of the passions, offending the gods, and deviating from divine law in a way that brings punishment and suffering upon oneself. We have also seen that translators of Greek texts utilizing these terms have drawn upon a range of English words in order to account for contextual nuance, and that in the case of Aristotelian hamartia, scholars have engaged in rigorous debate concerning the ways that the word might best be conveyed in the target language. Scholarly discussions in classics and philosophy have been marked by divergent interpretations of the "Aristotelian doctrine of hamartia" and by detailed arguments about the precise meaning not only of the term but also of an over-arching theory of human error.

The same may be said of scholarly discussions in fields such as early Christianity and theology about a "New Testament doctrine of sin" or, more frequently, a "Pauline doctrine of sin." But whereas certain figures in the study of Aristotelian hamartia have sought to push back against a formalized doctrine, the technical nature of the term, and even rigid translation practices, this kind of critical discourse is sorely lacking in the study of the NT. In the final section of this essay I offer a starting point for this kind of critical discourse by showing that in at least one NT text, 1 Corinthians, hamartia reflects some of the flex-

23 Note that the fourth occurrence in the passage is translated as "wrongs," presumably because it is an offense against humans rather than against gods. 
ibility seen in the literature already surveyed and by arguing that the English word "sin" is not a helpful translation. Before turning to 1 Corinthians, though, we must ask whether 1st century Greek texts dealing with Judean traditions will add any further options to the semantic range of hamartia.

As with Musonius Rufus and Epictetus, Philo of Alexandria uses hamartia and related terms in many ways, ranging from inaccurate statements (De opifcio mundi 21, 47; De posteritate Caini 57-58) and perceptual errors (De Cherubim $65-66,70$ ), to having irrational passions (De Specialibus legibus 1.19o-191) and bad intentions (Legum alligoriae 2.61), to speaking against the Lord (Leg. 2.78) and not properly recognizing the true God or following his ways (Spec. 1.53, 79). Hamartèmata may be committed against humans or gods (Spec. 1.100, 234), are evaluated with respect to the intention of the agent (Spec. 1.227, 235, 260), and often stem from a lack of knowledge or improper education (Spec. 1.53, 79). But unlike other authors in our survey, there are different variables at play. One variable common to nearly all Greek texts dealing with Judean traditions is the history of the transmission of concepts from Hebrew to Greek via the Septuagint. The Septuagint contains cases of semantic expansion, where one Hebrew root is translated into a number of different Greek terms, as happens in Ezekiel 33-34, where the Hebrew term 'wn, commonly translated as "misdeed," is translated into four different Greek words to account for differentiation in political context: anomia ("lawlessness"), asebeia ("impiety"), hamartia ("sin"), and adikia ("injustice") (Hubler 2007: 947), but more often the trend is toward semantic leveling, where a number of different Hebrew roots have been gathered under a smaller number of Greek terms (Quell 1964: 267-271).24 At issue with semantic leveling is a greater emphasis on hamartia as a multipurpose term that can cover a very broad range of actions including bending or twisting ('wh), rebelling ( $p s h$ '), and erring (shgh). Another complication is that although hamartia is regularly used in the LXx for the Hebrew ht', hamartia only conveys one aspect of the Hebrew term. $H t^{\prime}$ refers both to wrongdoing and to the ritual used to remove it, and yet hamartia indicates only the former; thus there is some confusion in the Greek that is cleared up by English translations using "sin" and "sin-offering" to account for context (Perkins 2007: 45).

A second variable is the inclusion of the Judean categories of ritual and moral impurity and their potential overlap with hamartia. Philo of Alexandria, for example, associates moral impurity (but not ritual impurity) with hamartia,

24 Although there are others, the four Hebrew verbs that are most often translated as hamartia in the LXx are ht', psh', 'wh, and shgh (Quell 1964: 270-271). 
and emphasizes the importance of purifying one's soul. ${ }^{25}$ Neither the association of an impure soul with hamartia nor the goal of purifying one's soul is uniquely Judean; nevertheless, emphasis upon sacrificial acts and atonement for an impure soul and a posited analogical relationship with ritual impurity and ritual purification (Philo, Spec.1.256-261, for example) is not found outside those texts concerned with Judean traditions. Thus in addition to the range of options already discussed for hamartia, when we turn to 1 Corinthians, we will also have another option associated with the Judean concept of moral impurity.

\section{Hamartia in 1 Corinthians}

Hamartia and its cognates (hamartano, hamartolos, and prohamartano), appear in five of Paul's seven undisputed letters: Romans, 1 and 2 Corinthians, 1 Thessalonians, and Galatians. Taken together, there are 83 occurrences in these letters, all of which are translated as "sin" in the New Revised Standard Version (NRSV) and the Revised Standard Version (RSV). ${ }^{26}$ In what follows, I examine each of the occurrences of hamartia in 1 Corinthians in order to show that semantic differentiation in the target language is possible, historically plausible, and can offer several benefits that contribute to a better understanding of Paul's ideas about morality. Much more could be said with reference to the content of each of the passages under discussion, but I limit the discussion to points directly related to the issues of semantic flexibility and translation.

There are 12 occurrences of hamartia-related terms in 1 Corinthians, the first two of which are found in 1 Cor 6:18:

The body is meant not for fornication but for the Lord, and the Lord for the body. And God raised the Lord and will also raise us by his power. Do you not know that your bodies are members of Christ? Should I therefore take the members of Christ and make them members of a prostitute? Never! Do you not know that whoever is united with a prostitute becomes

25 Philo follows the Biblical tradition in associating "sin" with moral impurity but not with ritual impurity; his innovation is the analogical relationship between the two (Klawans 2000, 64-66).

26 In fact, of the 269 occurrences of hamartia and its cognates in the NT, all but two (Acts 25:8 and 1 Peter 2:20) are translated as "sin." As mentioned previously, the focus of the study is on the NRSv because of its reputation as the best translation to use in academic settings. 
one body with her? For it is said, "The two shall be one flesh." But anyone united to the Lord becomes one spirit with him. Shun fornication! Every sin [pan hamartēma] that a person commits is outside the body; but the fornicator sins [hamartanei] against the body itself. Or do you not know that your body is a temple of the Holy Spirit within you, which you have from God, and that you are not your own? For you were bought with a price; therefore glorify God in your body. (1 Cor 6:13b-20, NRSV)

An injunction against fornication is found in 6:13b and 6:18, and interwoven with this injunction is evidence that Paul thinks the hamartèma under discussion might be remedied with further teaching. He repeats the phrase, "do you not know," three times, and follows it each time with instruction. First, that human bodies can be "members of Christ"; second, that the union of one of those members with sexual impurity pollutes that body, and by extension, both the other "members of Christ" and the spirit ( pneuma) of the Lord; third, that one's body contains "the holy spirit" ( pneuma) from God and that therefore the body belongs to God.

Paul's exhortation toward what he takes to be proper moral behavior rests upon the concept of participation in Christ, which he explains in the three points about the ways in which bodies can mix, via the divine spirit ( pneuma), both with each other and with Christ. He notes that the intermixing of human bodies with the pneuma can result in cross-contamination. Viewed within a realist version of participation in Christ, Paul would be explaining that different types of materials interpenetrate each other and thus can either contaminate or purify one another (Stowers 2008: 357-360). This concept of mixing or interpenetration is, for Paul, extremely powerful; powerful enough to explain human relatedness, physical participation in Christ, and the potential dangers of physically mixing with the wrong kind of people. Paul seems to think that if only the Corinthians knew about the potential consequences, they would not intermingle themselves with anything harmful, never mind a prostitute. Through his emphasis on a lack of knowledge, Paul implies that the mistake was made because of ignorance or improper education. He thinks that having the knowledge would be enough to convince a person not to engage in fornication, and thus he explains how moral impurity can serve to compromise the integrity both of the individual and of the group. Becoming one flesh, not just figuratively but physically, can corrupt one's own being, other members of the body of Christ, and Christ himself.

In this light, Paul's use of hamartia in 1 Cor 6:18 is consistent with the kind of misguided behavior that results from a lack of knowledge. Paul attempts to curtail this behavior through instruction, which shows that he views the 
injurious actions either as mistakes based upon an ignorance of certain facts (the laws of intermixing) or upon an error of judgment (the bad choice of sexual partners). I see no compelling reason to use the word "sin" in this passage; if we want to align the target language with the source language, then $\sin$ (used to designate a willful or voluntary offense against god, with possible soteriological implications) is technically not an inappropriate translation. The primary problem addressed by Paul is one of ignorance or bad judgment, which results in harm to individual and corporate purity. Perhaps a fitting translation would be, "Every misdeed that a person commits is outside the body; but the fornicator wrongs the body itself." Here, "misdeed" captures the idea that the person did something against moral purity, but that it was not an action chosen with full knowledge of the implications, while "wrongs" highlights the fact that the misdeed does in fact have injurious potential.

The next three occurrences are in 1 Cor 7 , which deals with the potential conflict arising from a constellation of issues revolving around desire, selfcontrol, service to the Lord, and marriage. Like the last passage, Paul offers a teaching designed to enable his readers to make better choices about their behavior:

In whatever condition you were called, brothers and sisters, there remain with God. Now concerning virgins, I have no command of the Lord, but I give my opinion as one who by the Lord's mercy is trustworthy. I think that, in view of the impending crisis, it is well for you to remain as you are. Are you bound to a wife? Do not seek to be free. Are you free from a wife? Do not seek a wife. But if you marry, you do not sin [ouch hēmartes] and if a virgin marries, she does not sin [ouch hèmarten]. Yet those who marry will experience distress in this life, and I would spare you that. I mean, brothers and sisters, the appointed time has grown short... (7:24-29a, NRSV)

Here, Paul encourages the Corinthians to remain as they are with reference to marital status, with emphasis on the fact that this is not an exhortation from God, but rather Paul's own speculative advice. This alone should speak against using the word sin. It is clear that a willful violation of divine law or God's will is impossible in this case because there is no divine decree to violate! Within the context of 1 Cor 7 , Paul's discussion of marriage falls into an ethical category known as the moral indifferents (adiaphora), which is to say that the appropriate behavior depends not upon a particular action's being inherently good or bad, but instead upon the circumstance and context in which a person finds 
him or herself. Paul does offer an argument against marriage, to the effect that it would add undue distress to one's life, but this distress would be tolerable and in fact welcome in light of a worse possibility, namely, not exercising selfcontrol: "If anyone thinks that he is not behaving properly toward his fiancée, if his passions are strong, and so it has to be, let him marry as he wishes; it is no sin [ouch hamartanei]. Let him marry" (1 Cor 7:35-36). Here, too, Paul offers his own speculation about which kinds of actions would be better than others and thus appears to be saying that the marriage in itself is not wrong, but rather the circumstances and the state of mind leading up to the marriage. For these passages in 1 Cor 7 , then, I suggest "But if you marry, you do not do wrong and if a virgin marries, she does not do wrong" and "let him marry as he wishes; it is not wrong. Let him marry."

The situation in 1 Cor 8 resembles that of 1 Cor 6 insofar as Paul attempts to remedy problematic behavior by explaining that the behavior has implications beyond what might have been expected:

Since some have become so accustomed to idols until now, they still think of the food they eat as food offered to an idol; and their conscience, being weak, is defiled. 'Food will not bring us close to God.' We are no worse off if we do not eat, and no better off if we do. But take care that this liberty of yours does not somehow become a stumbling block to the weak. For if others see you, who possess knowledge, eating in the temple of an idol, might they not, since their conscience is weak, be encouraged to the point of eating food sacrificed to idols? So by your knowledge those weak believers for whom Christ dies are destroyed. But when you thus sin [hamartanontes] against members of your family, and wound their conscience when it is weak, you sin [hamartanete] against Christ. Therefore, if food is a cause of their failing, I will never eat meat, so that I may not cause one of them to fall. (8:10-13, NRSV)

In this passage, some who have rightly understood that there is nothing inherently wrong with any kind of food, even that which has been sacrificed to idols, are being observed by others who do not yet understand this concept. Seeing others eating meat that they think is polluted has somehow caused problems for those who do not yet understand that meat is neither good nor bad in itself. Thus the knowledge that frees people from worrying about what types of food to eat has been misunderstood, and has led to destruction. The problem clearly involves the inadvertent harming of family members (presumably those who are "members of Christ") and by extension, of Christ. As with the 1 Cor 6 
passage, the action, while inadvertent, nevertheless causes harm and so I suggest, "But when you thus do wrong against members of your family, and wound their conscience when it is weak, you do wrong against Christ."

The final five occurrences are in 1 Cor 15, and here the usage of the term is different. Rather than referring to particular actions that he finds problematic, Paul uses hamartia within a constellation of terms depicting the differences between the dusty, perishable, weak and mortal existence of humans since Adam and the heavenly, imperishable, powerful and immortal existence of those resurrected with Christ:

There are both heavenly bodies and earthly bodies, but the glory of the heavenly is one thing, and that of the earthly is another. There is one glory of the sun, and another glory of the moon, and another glory of the stars; indeed, star differs from star in glory. So it is with the resurrection of the dead. What is sown is perishable, what is raised is imperishable. It is sown in dishonor, it is raised in glory. It is sown in weakness, it is raised in power. It is sown in a physical body, it is raised in a spiritual body. If there is a physical body, there is also a spiritual body. Thus it is written, "The first man, Adam, became a living being"; the last Adam became a life-giving spirit. But it is not the spiritual that is first, but the physical, and then the spiritual. The first man was from the earth, a man of dust; the second man is from heaven. As was the man of dust, so are those who are of the dust; and as is the man of heaven, so are those who are of heaven. Just as we have borne the image of the man of dust, we will also bear the image of the man of heaven. What I am saying, brothers and sisters, is this: flesh and blood cannot inherit the kingdom of God, nor does the perishable inherit the imperishable (1 Cor 15:40-50).

The dichotomy between the earthly and the heavenly man is borne out through the differing value of each kind's physicality, representing two ends of a qualitative spectrum of substance (or, a hierarchy of being, Stowers 2008: 355-356). According to this spectrum, it is only natural that the lower, earthly end would be characterized by mortality (death), weakness, and a host of other related or corollary features. Concerning the human, these traits would naturally include problems such as mental and emotional weaknesses manifesting themselves in overwhelming passions, ignorance, bad judgment, and other flaws of character that lead to harmful, hurtful, and injurious behavior. Despite this being the natural condition for dusty, mortal men, Paul nevertheless exhorts the Corinthians to try to keep a clear head and thus not go astray: "Come to a sober and right mind and sin no more [mé hamartanete]; for some people have no 
knowledge of God. I say this to your shame" (1 Cor 15:34). Beings at this lower end of the spectrum of substance are prone to do wrong and make mistakes by the very nature of their physicality, but it does not mean that Paul will not encourage them to do better. I suggest the translation, "Come to a sober and right mind and do not go astray"; Paul is not accusing the Corinthians of willful deviations from God's will. Rather, he is exhorting them to pull themselves together as best they can and stop making the kinds of mistakes that will only result in further distress.

When Paul associates hamartia with death, he is simply articulating one aspect of the imperfect set of features attributed to those inhabiting the lower end of the spectrum:

"Where, $\mathrm{O}$ death, is your victory?

Where, $\mathrm{O}$ death, is your sting?"

The sting of death is $\sin [$ he hamartia], and the power of $\sin [$ [he dunamis tês hamartias] is the law (1 Cor 15:55-56).

Again, because Paul is describing the natural situation of humankind, use of the word sin here seems overwrought, and I see no reason why the passage could not read, "The sting of death is wrongdoing and the power of wrongdoing is the law." But, according to Paul, although humans may now be dwelling in the lower part of existence, they will soon be resurrected and inhabit the upper end: "Listen, I will tell you a mystery! We will not all die, but we will all be changed, in a moment, in the twinkling of an eye, at the last trumpet. For the trumpet will sound and the dead will be raised imperishable, and we will be changed. For this perishable body must put on imperishability, and this mortal body must put on immortality" (1 Cor 15:51-53). This change happens through human resurrection, but the possibility of human resurrection depends upon Christ's resurrection: "If Christ has not been raised, your faith is futile and you are still in your sins [tais hamartiais humōn]" (1 Cor 15:17). As an alternative, this passage could read, "and you are still in your misdeeds." The emphasis is upon the movement from the earthly weakened state of being to the heavenly one; "misdeeds" captures the actions stemming from mental weakness and error better than "sins."

Paul's use of hamartia and its cognates in 1 Cor aligns neither with the modern understanding that sin is a willful offense against God that often comes with soteriological consequences nor with the idea that sin is a congenital angst that bears itself out as the kind of guilt that only Christ can fix. We saw that in 1 Cor 6 and 8, Paul identified certain behaviors as wrongdoings or misdeeds because they were done out of ignorance. In particular, the misdeeds 
were carried out because the agents did not realize that the actions had such far-reaching consequences with regard to moral purity and the integrity of the individual and the corporate body. Further, we saw that in 1 Cor 7 , Paul set forth his own moral advice about marriage but qualified his advice by saying that those who did not follow it were not really going astray because circumstance might dictate a different course of action. Finally, in 1 Cor 15, Paul associates hamartia with a set of characteristics that he understands to be defining features of earthly human beings: dusty, mortal, weak, and prone to clouded thinking that can lead to harmful behaviors and moral failures. It is with this last usage of hamartia, that I propose a slight modification to what is often taken to be a central teaching of Pauline thought:

For I handed on to you as of first importance what I in turn had received: that Christ died for our shortcomings [tōn hamartiōn hèmōn] in accordance with the scriptures, and that he was buried, and that he was raised on the third day in accordance with the scriptures, and that he appeared to Cephas, then to the twelve (1 Cor 15:3-5).

If "Christ died for our shortcomings" does not sound as dramatic as "Christ dies for our sins," then my choice was apt. While it may feel comfortable and familiar to assume that Paul and his readers would have understood hamartia to mean the same thing that "sin" means for English speakers today, a close reading of his use of the term in 1 Cor simply does not support such an assumption.

As this study has shown, translation practices concerning the Greek word hamartia diverge between scholars who focus on different sets of literature. In literature traditionally defined as philosophical, hamartia is translated in a variety of ways to account for the multiple ways that an agent's intentions can result in harmful, wrong, or less-than-ideal actions. This variety is retained, to some extent, in the translation of Judean texts, but virtually disappears in English translations of the New Testament. The divergent practices trade upon modern assumptions about the nature of religion in antiquity and the essentially religious nature of the concept of sin. Perhaps because of the stillpervasive Augustinian-Lutheran idea that Paul's letters are expressions of the universal human problem of sin and thus, as Krister Stendahl puts it, "documents of human consciousness," translators have been unable to bring themselves to move away from the word sin and all that it entails (Stendahl 1963:199). In light of ancient evidence for the flexibility of hamartia, it becomes difficult to believe that not only Paul but also all of the other New Testament authors whose writings span roughly 70 years and originate from multiple geographical locales, could have used the term in only one way. The monolithic translation 
of hamartia as sin, then, seems to stem from ideology rather than from attention to philology or history. Placing modern theological understandings of sin onto authoritative religious texts through unreflective translation practices not only produces anachronism but it also reinforces the supposed truth of those theological concepts in a way that protects them from critical analysis.

\section{References}

Aristotle (Trans. by Christopher Rowe [2002]). Nicomachean Ethics. Introduction by Sarah Broadie. New York; Oxford: Oxford University Press.

Blackburn, Simon (2005). Oxford Dictionary of Philosophy. Oxford: Oxford University Press.

Bremer, Jan Maarten (1969). Hamartia: Tragic Error in the Poetics of Aristotle and in Greek Tragedy. Amsterdam: Adolf M. Hakkert.

Epictetus (Trans. by Elizabeth Carter [1807]). The Works of Epictetus: Consisting of His Discourses in Four Books Preserved by Arrian, the Enchiridion, and Fragments. 4th edition. London: Rivington.

— (Trans. by Thomas Wentworth Higginson [1890]). The Works of Epictetus Consisting of His Discourses, In Four Books, The Enchiridion, and Fragments. New and Revised Edition. Boston: Little, Brown, and Company.

— (Trans. P. E. Matheson [1916]). The Discourses and Manual Together with Fragments of his Writings. Oxford: Clarendon Press.

— (Trans. by W. A. Oldfather [1925]). 2 vols. Loeb Classical Library. Cambridge: Harvard University Press.

Eyl, Jennifer (2014). Semantic voids, New Testament translation, and anachronism: The case of Paul's use of ekklēsia. Method \& Theory in the Study of Religion 26: 315-339.

Halliwell, Stephen (1998). Aristotle's Poetics. 2nd edition. Chicago: University of Chicago Press.

Hubler, J. Noel (2007). To the reader of Ezekiel. In Albert Pietersma and Benjamin G. Wright (eds.), A New English Translation of the Septuagint, 946-948. New York: Oxford University Press.

Kim, Ho (2010). Aristotle's hamartia reconsidered. Harvard Studies in Classical Philology 105: $33-52$.

Klawans, Jonathan (2000). Impurity and Sin in Ancient Judaism. New York: Oxford University Press.

Kraemer, Ross, \& Jennifer Eyl (forthcoming). Translating women: the perils of genderinclusive translation of the New Testament. In Charles Carter (ed.), Celebrate Her for the Fruit of Her Hands: Studies in Honor of Carol L. Meyers. Winona Lake, IN: Eisenbrauns. 
LaCocque, André (1995). Sin and guilt. In Mircea Eliade (ed.) The Encyclopedia of Religion, Volume 13, 325-331. New York: Simon \& Schuster Macmillan.

Lutz, Cora E. (1947). Musonius Rufus, The Roman Socrates. New Haven: Yale University Press.

Martin, Dale B. (2008). Pedagogy of the Bible. Louisville: Westminster John Knox Press. Musonius Rufus (Trans. by Cynthia King [2011]). Lectures \& Sayings. Revised Edition. CreateSpace.

Perkins, Larry J. (2007). To the reader of Exodus. In Albert Pietersma and Benjamin G. Wright (eds.), A New English Translation of the Septuagint, 43-51. New York: Oxford University Press.

Quell, Gottfried (1964). Sin in the от. In Gerhard Kittel (ed.) Theological Dictionary of the New Testament, Volume 1, 267-286. Grand Rapids: Eerdmans.

Quinn, Philip L. (1998). Sin and guilt. In Edward Craig (ed.) The Routledge Encyclopedia of Philosophy, Volume 8, 791-796. London; New York: Routledge.

Sherman, Nancy (1992). Hamartia and virtue. In Amélie Oksenberg Rorty (ed.) Essays on Aristotle's Poetics, 177-196. Princeton: Princeton University Press.

Stendahl, Krister (1963). The apostle Paul and the introspective conscience of the West. Harvard Theological Review 56(3): 199-215.

Stowers, Stanley K. (2008). What is "Pauline participation in Christ"? In Fabian E. Udoh (ed.) Redefining First-Century Jewish and Christian Identities: Essays in Honor of Ed Parish Sanders, 352-371. Notre Dame: University of Notre Dame Press.

- (2011). Kinds of Myth, Meals, and Power: Paul and the Corinthians. In Ron Cameron and Merrill P. Miller (eds.) Redescribing Paul and the Corinthians, 105-150. Atlanta: Society of Biblical Literature.

"Sin." Online: http://dictionary.reference.com/browse/sin. [accessed on January 21, 2013]. - Online: http://www.merriam-webster.com/dictionary/sin. [accessed on January 21, 2013].

Online: http://www.oed.com/view/Entry/180030?result=1\&rskey=2yftIf\&. [accessed on January 21, 2013].

Online: http://en.wikipedia.org/wiki/Sin. [accessed on January 21, 2013]. 